\title{
Nickel(II) Complexes of Hydrazone of Isoniazid and Their Magneto-Spectral, Electrochemical, Thermal and Antimicrobial Investigations
}

\author{
Surendra Prasad ${ }^{1}$ and Ram K. Agarwal ${ }^{1,2}$ \\ ${ }^{1}$ School of Chemical Sciences, Faculty of Science and Technology, The University of the South Pacific, Private Mail Bag, \\ Laucala Campus, Suva, Fiji \\ ${ }^{2}$ Department of Chemistry, Lajpat Rai Postgraduate College, Sahibabad, Ghaziabad 201005, India
}

Correspondence should be addressed to Surendra Prasad,prasad_su@usp.ac.fj

Received 15 July 2008; Accepted 13 August 2008

Recommended by Tai Lau

The synthesis of novel nickel(II) complexes with new ligand derived from hydrazone of isoniazid has been reported. The complexes have general compositions $\left[\mathrm{Ni}(\mathrm{L})_{2} \mathrm{X}_{2}\right]$ or $\left[\mathrm{Ni}(\mathrm{L})_{3}\right]\left(\mathrm{ClO}_{4}\right)_{2}$, where $\mathrm{L}=\mathrm{N}$-isonicotinamido-furfuraldimine (INH-FFL) and $\mathrm{X}=\mathrm{Cl}^{-}$or $\mathrm{NCS}^{-}$. The ligand hydrazone behaves as neutral bidentate ( $\mathrm{N}$ and $\mathrm{O}$ donor) through the carbonyl oxygen and azomethine nitrogen. On the basis of elemental analysis, molecular weight determinations, magnetic susceptibility/moment, thermogravimetric, electrochemical, and spectroscopic studies, the new complexes have been characterized with octahedral geometry. The antibacterial and antifungal studies of the present complexes show that they are moderate antibacterial and antifungal agents.

Copyright ( 2008 S. Prasad and R. K. Agarwal. This is an open access article distributed under the Creative Commons Attribution License, which permits unrestricted use, distribution, and reproduction in any medium, provided the original work is properly cited.

\section{Introduction}

The synthesis of transition metal complexes with Schiff bases of nitrogen and oxygen donor has stimulated interest due to their vast variety of biological activities ranging from pharmacological, antitumour, fungicide, bactericide, anti-inflammatory, and antiviral activities $[1,2]$. We have recently published some lanthanide(III) complexes of semicarbazones [3] and oxovanadium(IV) [4, 5], platinum(II) [6], cobalt(II), and nickel(II) [2, 7] complexes of thiosemicarbazones derived from 4-aminoantipyrine. The antibacterial and antifungal properties of the thiosemicarbazone ligands and their cobalt(II) [2, 7], nickel(II) [7], and oxovanadium(IV) [5] complexes have also been examined. In continuation of our work on hydrazones of isoniazid (a drug of proven therapeutical importance [8]) complexes of metal ions [9], the present work describes the synthesis, magnetospectral, electrochemical, thermal, and biological studies of a novel series of $\mathrm{Ni}(\mathrm{II})$ complexes of $\mathrm{N}$-isonicotinamidofurfuraldimine (INH-FFL) (Figure 1).

\section{Experimental}

The nickel(II) salt, $\mathrm{NiCl}_{2} \cdot 6 \mathrm{H}_{2} \mathrm{O}$, was obtained from $\mathrm{BDH}$ and used as received. $\mathrm{Ni}(\mathrm{NCS})_{2}$ and $\mathrm{Ni}\left(\mathrm{ClO}_{4}\right)_{2}$ were prepared by methods reported elsewhere [7]. The hydrazone of isoniazid viz. INH-FFL was synthesized by following a general method reported by us [9] (yield ca. 80\%). A general method was used for the synthesis of the nickel(II) complexes [7]. A hot ethanolic solution of the corresponding nickel(II) salt was mixed with a hot ethanolic solution of the hydrazone ligand in molar ratio 1:2, and 1:3 for $\left[\mathrm{Ni}(\mathrm{L})_{2} \mathrm{X}_{2}\right]$ and $\left[\mathrm{Ni}(\mathrm{L})_{3}\right]\left(\mathrm{ClO}_{4}\right)_{2}$ complexes, respectively. The reaction mixture was refluxed on a water bath for $\sim 2$ hours. On cooling the reaction mixture at room temperature, the colored complexes precipitated out in each case. The complexes were filtered out, recrystallized, washed with ethanol, and dried over $\mathrm{P}_{4} \mathrm{O}_{10}$ under vacuum.

The molecular weight of the complexes was determined cryoscopically using Beckmann thermometer. The nickel contents of the complexes were determined complexomet- 


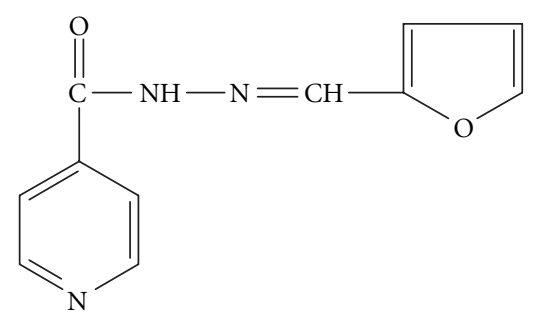

Figure 1: N-Isonicotinamido-furfuraldimine (INH-FFL)

rically after decomposing with conc. $\mathrm{H}_{2} \mathrm{SO}_{4}$ and $\mathrm{H}_{2} \mathrm{O}_{2}$ [7], while the chlorine was estimated by reported method [10]. The thiocyanate was estimated argentometrically. The perchlorate was estimated by the method reported in our previous work [7]. The percentage of nitrogen was determined by Kjeldahl method. The conductivity and the magnetic measurements of the complexes were performed using a Toshniwal conductivity bridge and Evans magnetic balance, respectively $[2,7]$. The infrared spectra and diffused reflectance spectra of the solid complexes were recorded on a Perkin Elmer FT-IR infrared spectrophotometer model 521 and Beckmann DK-2A spectrophotometer, respectively. Thermogravimetric analyses of the complexes were performed on Perkin Elmer Pyris Diamond in static air with unlidded small platinum boat sample holder at heating rate $6^{\circ} \mathrm{C} \mathrm{min}^{-1}$. The antibacterial and antifungal activities of the representative nickel(II) complexes and standard drugs (ampicillin and tetracycline) were screened using reported methods [2].

\section{Results and Discussion}

The reaction of nickel(II) salts with INH-FFL resulted in the formation of $\left[\mathrm{NiX}_{2}(\mathrm{~L})_{n}\right]$, where $\mathrm{X}=\mathrm{Cl}^{-}$or $\mathrm{NCS}^{-}, n=2$, and $\left[\mathrm{Ni}(\mathrm{L})_{n}\right] \mathrm{X}_{2}$, while $\mathrm{X}=\mathrm{ClO}_{4}{ }^{-}, n=3$. The analytical data, molar conductance in nitrobenzene, and molecular weights of the complexes are presented in Table 1. The complexes were quite stable and could be stored for several weeks without any appreciable change but decomposed on heating beyond $250^{\circ} \mathrm{C}$. The paramagnetism observed for the present complexes ranges from 3.1-3.2 BM (Table 1) and is consistent with the octahedral stereochemistry [7].

The infrared frequencies in the present ligand associated with amide group (carbonyl-oxygen), azomethinenitrogen $(\mathrm{C}=\mathrm{N})$, and heterocyclic nitrogen are expected to be influenced on complex formation with nickel(II). Generally, amides show two absorption bands: (i) the carbonyl absorption band near $1640 \mathrm{~cm}^{-1}$ (amide-I band) and (ii) strong band in the $1600-1500 \mathrm{~cm}^{-1}$ region (amideII band). The amide-I band in INH-derivatives, however, appeared at $1655 \mathrm{~cm}^{-1}$ [11]. In the infrared spectra of the complexes, a considerable negative shift in $v(\mathrm{C}=\mathrm{O})$ was observed indicating a decrease in the stretching force constant of $(\mathrm{C}=\mathrm{O})$ as a consequence of coordination through the carbonyl oxygen atom of the ligand. Another important band occurs at $1585 \mathrm{~cm}^{-1}$ range is attributed to $v(\mathrm{C}=\mathrm{N})$ (azomethine) mode [12]. In spectra of all the complexes, this band is shifted to lower wave number and appears in 1545-
$1535 \mathrm{~cm}^{-1}$ region indicating the involvement of $\mathrm{N}$-atom of the azomethine group in coordination [12]. The overall infrared spectral evidence suggests that the present ligand acts as bidentate ligand and coordinates through amide oxygen and azomethine nitrogen atoms forming a fivemembered chelate ring. The three fundamental absorptions in $\left[\mathrm{Ni}(\mathrm{NCS})_{2}(\mathrm{~L})_{2}\right]$ complex, that is, C-N stretching $\left(v_{1}\right)$, $\mathrm{C}-\mathrm{S}$ stretching $\left(v_{3}\right)$, and $\mathrm{N}-\mathrm{C}-\mathrm{S}$ bending $\left(v_{2}\right)$ identified at 2040-2035, 845-830, and 470-465 $\mathrm{cm}^{-1}$ region are associated with the terminal N-bonded isothiocyanate ions [7]. In the perchlorato complex, the presence of the $v_{3}(1100-$ $\left.1090 \mathrm{~cm}^{-1}\right)$ and $v_{4}\left(625-620 \mathrm{~cm}^{-1}\right)$ bands indicates that the $T_{d}$ symmetry of $\mathrm{ClO}_{4}{ }^{-}$is maintained in the complex. It suggests the presence of $\mathrm{ClO}_{4}{ }^{-}$outside the coordination sphere [13].

The electronic spectra of the octahedral nickel(II) complexes exhibit spectra showing three spin-allowed transitions in $7000-11000 \mathrm{~cm}^{-1}\left(v_{1}\right), 15000-19000 \mathrm{~cm}^{-1}\left(v_{2}\right)$, and $25000-29000 \mathrm{~cm}^{-1}\left(v_{3}\right)$ regions $[2,7]$. In the present complexes, the electronic spectra were very similar to each other and consist of bands in 8200-10930 $\left\{v_{1},{ }^{3} A_{2 g}(\mathrm{~F}) \rightarrow{ }^{3} T_{2 g}(\mathrm{~F})\right\}$, 17540-17700 $\left\{v_{2},{ }^{4} T_{1 g}(\mathrm{~F}) \rightarrow{ }^{4} A_{2 g}(\mathrm{~F})\right\}$, and 26950-27500 $\mathrm{cm}^{-1}\left\{v_{3},{ }^{4} T_{1 g}(\mathrm{~F}) \rightarrow{ }^{4} T_{1 g}(\mathrm{P})\right\}$ regions, which clearly indicated the octahedral stereochemistry of the complexes.

The thermogravimetric results of representative complexes clearly suggested the absence of any water molecule in the complexes. During $160-265^{\circ} \mathrm{C}$ temperature range, the weight loss corresponds to $37.21-39.34 \%$ indicates the loss of one molecule of INH-FFL, while second ligand molecule evaporated off at $\sim 400^{\circ} \mathrm{C}$. Finally, at $\sim 600^{\circ} \mathrm{C}$, NiO formation takes place according to the following general equation:

$$
\begin{aligned}
{\left[\mathrm{Ni}(\mathrm{INH}-\mathrm{FFL})_{2} \mathrm{Cl}_{2}\right] \stackrel{175-265^{\circ} \mathrm{C}}{\longrightarrow}\left[\mathrm{Ni}(\mathrm{INH}-\mathrm{FFL}) \mathrm{Cl}_{2}\right] } \\
\stackrel{325-400^{\circ} \mathrm{C}}{\longrightarrow}\left[\mathrm{NiCl}_{2}\right] \stackrel{515-600^{\circ} \mathrm{C}}{\longrightarrow} \mathrm{NiO} .
\end{aligned}
$$

The antibacterial activities of the nickel(II) complexes and standard drugs (ampicillin and tetracycline) were screened by agar cup method in DMF solvent at a concentration of $50 \mu \mathrm{g} / \mathrm{mL}$ under identical conditions. The results were checked against gram positive bacteria, Bacillus subtilis and Staphylococcus aureus, and gram negative bacteria, Escherichia coli and Salmonella typhi, which show that the nickel(II) complexes of INH-FFL have moderate antibacterial activities against these bacteria (Table 2). The screened antifungal activities of the complexes against two fungi (Aspergillus niger and Candida albicans) show that they are less active compared to salicylic acid and appear to be moderate antifungal agents (Table 2). The antibacterial and antifungal activities of the present complexes were also compared with the activity results of some other nickel(II) complexes having different ligands (Table 2) [14-17]. It was found that the present complexes are less potent bactericides with respect to few reported nickel(II) complexes [14, 15], while some other complexes have almost comparable $[16,17]$ or less [17] antibacterial and antifungal activities. However, the experimental conditions for complexes reported in literature are different [14-17].

The overall experimental evidences thus show that the studied nickel(II) complexes, $\left[\mathrm{Ni}(\mathrm{L})_{2} \mathrm{X}_{2}\right]$ and 
TABLE 1: Analytical, conductivity, molecular weight, and magnetic moment data of nickel(II) complexes of hydrazones of isoniazid.

\begin{tabular}{|c|c|c|c|c|c|c|c|c|c|}
\hline \multirow{2}{*}{ Complex } & \multirow{2}{*}{$\begin{array}{l}\text { Yield } \\
(\%)\end{array}$} & \multicolumn{5}{|c|}{ Analysis: found (calcd.) (\%) } & \multirow{2}{*}{$\begin{array}{l}\text { m.wt. fou- } \\
\text { nd (Calcd.) }\end{array}$} & \multirow{2}{*}{$\begin{array}{l}\Omega \mathrm{m}\left(\mathrm{ohm}^{-1}\right. \\
\left.\mathrm{cm}^{2} \mathrm{~mole}^{-1}\right)\end{array}$} & \multirow{2}{*}{$\begin{array}{l}\mu_{\text {eff }} \\
(\mathrm{BM})\end{array}$} \\
\hline & & $\mathrm{Ni}$ & $\mathrm{C}$ & $\mathrm{H}$ & $\mathrm{N}$ & Anion & & & \\
\hline$\left[\mathrm{NiCl}_{2}(\mathrm{INH}-\mathrm{FFL})_{2}\right]$ & 72 & $\begin{array}{c}10.47 \\
(10.53)\end{array}$ & $\begin{array}{c}47.00 \\
(47.14)\end{array}$ & $\begin{array}{c}3.18 \\
(3.21)\end{array}$ & $\begin{array}{c}14.90 \\
(15.00)\end{array}$ & $\begin{array}{c}12.55 \\
(12.67)\end{array}$ & $\begin{array}{c}555 \\
(560)\end{array}$ & 3.1 & 3.1 \\
\hline$\left[\mathrm{Ni}(\mathrm{NCS})_{2}(\mathrm{INH}-\mathrm{FFL})_{2}\right]$ & 68 & $\begin{array}{c}9.69 \\
(9.75)\end{array}$ & $\begin{array}{c}47.48 \\
(47.60)\end{array}$ & $\begin{array}{c}2.93 \\
(2.97)\end{array}$ & $\begin{array}{c}18.45 \\
(18.51)\end{array}$ & $\begin{array}{c}19.06 \\
(19.17)\end{array}$ & $\begin{array}{c}600 \\
(605)\end{array}$ & 3.3 & 3.2 \\
\hline$\left[\mathrm{Ni}(\mathrm{INH}-\mathrm{FFL})_{3}\right]\left(\mathrm{CIO}_{4}\right)_{2}$ & 65 & $\begin{array}{c}6.48 \\
(6.53)\end{array}$ & $\begin{array}{c}43.73 \\
(43.85)\end{array}$ & $\begin{array}{c}2.96 \\
(2.99)\end{array}$ & $\begin{array}{c}13.89 \\
(13.95)\end{array}$ & $\begin{array}{c}21.89 \\
(22.03)\end{array}$ & $\begin{array}{c}899 \\
(903)\end{array}$ & 51.8 & 3.2 \\
\hline
\end{tabular}

TABLe 2: Antifungal and antibacterial activities of nickel(II) complexes of INH-FFL and their comparison with the activity results of some other reported nickel(II) complexes [14-17].

\begin{tabular}{|c|c|c|c|c|c|c|}
\hline \multirow{3}{*}{ Complex } & \multicolumn{4}{|c|}{ Antibacterial activity } & \multirow{2}{*}{\multicolumn{2}{|c|}{ Antifungal action }} \\
\hline & \multicolumn{4}{|c|}{ Zone of inhibition in numbers } & & \\
\hline & B.s. & S.a. & E.c. & S.t. & A. niger & C. albicaus \\
\hline$\left[\mathrm{Ni}(\mathrm{INH}-\mathrm{FFL})_{2} \mathrm{Cl}_{2}\right]$ & 12 & 10 & 10 & 9 & ++ & ++ \\
\hline$\left[\mathrm{Ni}(\mathrm{INH}-\mathrm{FFL})_{2}(\mathrm{NCS})_{2}\right]$ & 16 & 15 & 15 & 14 & +++ & +++ \\
\hline$\left[\mathrm{Ni}(\mathrm{INH}-\mathrm{FFL})_{3}\right]\left(\mathrm{CIO}_{4}\right)_{2}$ & 13 & 11 & 12 & 11 & ++ & ++ \\
\hline Ampicillin & 24 & 22 & 17 & 16 & - & - \\
\hline Tetracycline & 18 & 17 & 21 & 22 & - & - \\
\hline Salicylic acid & - & - & - & - & ++++ & ++++ \\
\hline [Ni(HIBN)Cl] [14] & - & 38 & 40 & - & - & - \\
\hline $\mathrm{Ni}_{2} \mathrm{~L}^{1}[15]$ & - & 18 & 18 & - & - & - \\
\hline $\mathrm{Ni}_{2} \mathrm{~L}^{2}[15]$ & - & 20 & 21 & - & - & - \\
\hline$\left[\mathrm{Ni}(\mathrm{Pr}-\mathrm{BIAN})_{2}\right]\left(\mathrm{CIO}_{4}\right)_{2}[16]$ & na & 14 & 18 & - & - & - \\
\hline$\left[\mathrm{Ni}(\right.$ cyclam $\left.)(2 \text {-napthoata })_{2}\right][17]$ & 7 & 7 & 7 & 7 & +++ & +++ \\
\hline$\left[\mathrm{Ni}(\right.$ cyclam $\left.)(3 \text {-nitrobenzoata })_{2}\right][17]$ & 14 & 12 & na & na & + & + \\
\hline
\end{tabular}

HIBN: 2-hydroxy-1-naphthaldehyde)-3-isatin]-bishydrazone

$\mathrm{L}^{1}$ : 4-methyl-2,6-di-formylphenol

$\mathrm{L}^{2}$ : 4-t-butyl-2,6-di-formylphenol

Pr-BIAN: $b i s[N$-(2,6-diisopropylphenyl)imino]acenaphthene

na: No activity

$\left[\mathrm{Ni}(\mathrm{L})_{3}\right]\left(\mathrm{ClO}_{4}\right)_{2}$, display a coordination number six and have an octahedral environment around the metal ion. The complexes appear to be moderate antibacterial and antifungal agents.

\section{Acknowledgments}

The authors are thankful to URC of the University of the South Pacific for supporting finance for this research through Project nos. 6395-1321 and 6394-1321 (6C127-1321 and 6C126-1321) and Dr. Abdul Mohammed Hatha, Lecturer, Department of Biology, FST, USP for assisting in studying the biological properties of the compounds.

\section{References}

[1] A. Chaudhary, A. Phor, and R. V. Singh, "Potentially biodynamic tetraaza macrocycles and their manganese complexes : antiandrogen, antimicrobial and PDI studies," Bioinorganic Chemistry and Applications, vol. 3, no. 3-4, pp. 161-177, 2005.
[2] S. Prasad and R. K. Agarwal, "Cobalt(II) complexes of various thiosemicarbazones of 4-aminoantipyrine: syntheses, spectral, thermal and antimicrobial studies," Transition Metal Chemistry, vol. 32, no. 2, pp. 143-149, 2007.

[3] R. K. Agarwal and B. Prakash, "Studies on the effect of various anions and diphenyl sulfoxide on the stereochemistry of lanthanide(III) coordination compounds of $4\left[N-\left(2^{\prime}\right.\right.$-hydroxy- $1^{\prime}$ naphthalidene)amino] antipyrinesemicarbazone," Transition Metal Chemistry, vol. 30, no. 6, pp. 696-705, 2005.

[4] R. K. Agarwal, S. Prasad, and N. Gahlot, "Synthesis, spectral and thermal properties of some penta-coordinated complexes of oxovanadium(IV) derived from thiosemicarbazones of 4aminoantipyrine," Turkish Journal of Chemistry, vol. 28, no. 6, pp. 691-701, 2004.

[5] R. K. Agarwal and S. Prasad, "Synthesis, biological, spectral and thermal properties of oxovanadium(IV) complexes of N,N,S-containing ligands," Reviews in Inorganic Chemistry, vol. 26, no. 5, pp. 471-492, 2006.

[6] R. K. Agarwal and S. Prasad, "Synthesis and spectral investigations of some platinum metals ions coordination compounds of $4\left[\mathrm{~N}\right.$-(furan- $2^{\prime}$-carboxalidene)amino] antipyrine 
thiosemicarbazone and $4\left[\mathrm{~N}-\left(3^{\prime}, 4^{\prime}, 5^{\prime}\right.\right.$-trimethoxybenzalidene $)$ amino]antipyrine thiosemicarbazone," Turkish Journal of Chemistry, vol. 29, no. 3, pp. 289-297, 2005.

[7] R. K. Agarwal and S. Prasad, "Synthesis, spectroscopic and physicochemical characterization and biological activity of $\mathrm{Co}(\mathrm{II})$ and $\mathrm{Ni}(\mathrm{II})$ coordination compounds with 4-aminoantipyrine thiosemicarbazone," Bioinorganic Chemistry and Applications, vol. 3, no. 3-4, pp. 271-288, 2005.

[8] R. P. Sharma, A. K. Kothari, and N. K. Sharma, "Acneform eruptions and antitubercular drugs," Indian Journal of Dermatology, Venereology and Leprology, vol. 61, no. 1, pp. 26-27, 1995.

[9] R. K. Agarwal, L. Singh, D. K. Sharma, and R. Singh, "Synthesis, spectral and thermal investigations of some oxovanadium(IV) complexes of hydrazones of isonicotinic acid hydrazide," Turkish Journal of Chemistry, vol. 29, no. 3, pp. 309-316, 2005.

[10] J. Bassett, R. C. Denney, G. H. Jeffery, and J. Mendham, Vogel's Text Book of Quantitative Inorganic Analysis, Longman Scientific \& Technical, London, UK, 4th edition, 1986.

[11] R. K. Agarwal and R. K. Sarin, "Synthesis and characterization of some lanthanide(III) perchlorato complexes of hydrazones of isonicotinic acid hydrazide," Polyhedron, vol. 12, no. 19, pp. 2411-2415, 1993.

[12] R. K. Agarwal and J. Prakash, "Synthesis and characterization of thorium(IV) and dioxouranium(VI) complexes of 4- $[\mathrm{N}(2-$ hydroxy-1-naphthalidene)amino] antipyrine," Polyhedron, vol. 10, no. 20-21, pp. 2399-2403, 1991.

[13] M. B. Ferrari, G. G. Fava, E. Leporati, et al., "Synthesis, characterisation and biological activity of three copper(II) complexes with a modified nitrogenous base: 5-formyluracil thiosemicarbazone," Journal of Inorganic Biochemistry, vol. 70, no. 2, pp. 145-154, 1998.

[14] B. Murukan and K. Mohanan, "Synthesis, characterization, electrochemical properties and antibacterial activity of some transiton metal complexes with [(2-hydroxy-1naphthaldehyde)-3- isatin]-bishydrazone," Transition Metal Chemistry, vol. 31, no. 4, pp. 441-446, 2006.

[15] M. Tümer, D. Ekinci, F. Tümer, and A. Bulut, "Synthesis, characterization and properties of some divalent metal(II) complexes: their electrochemical, catalytic, thermal and antimicrobial activity studies," Spectrochimica Acta Part A, vol. 67, no. 3-4, pp. 916-929, 2007.

[16] U. El-Ayaan and A. A.-M. Abdel-Aziz, "Synthesis, antimicrobial activity and molecular modeling of cobalt and nickel complexes containing the bulky ligand: bis $[N-(2,6-$ diisopropylphenyl) imino] acenaphthene," European Journal of Medicinal Chemistry, vol. 40, no. 12, pp. 1214-1221, 2005.

[17] M. A. A. Al-Bari, M. K. B. Chowdhury, M. F. Hossen, M. M. Hossain, C. M. Zakaria, and M. A. U. Islam, "Novel nickel cyclam complexes with potent antimicrobial and cytotoxic properties," Journal of Applied Sciences Research, vol. 3, no. 11, pp. 1251-1261, 2007. 


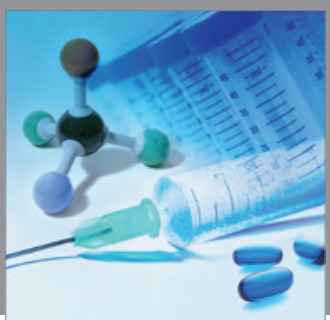

International Journal of

Medicinal Chemistry

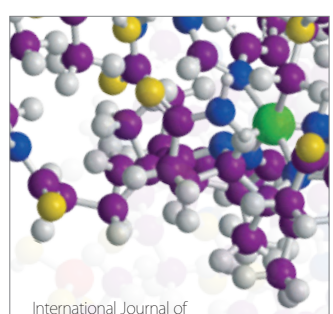

Carbohydrate Chemistry

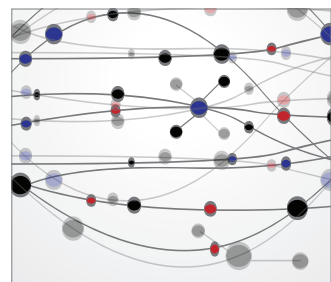

The Scientific World Journal
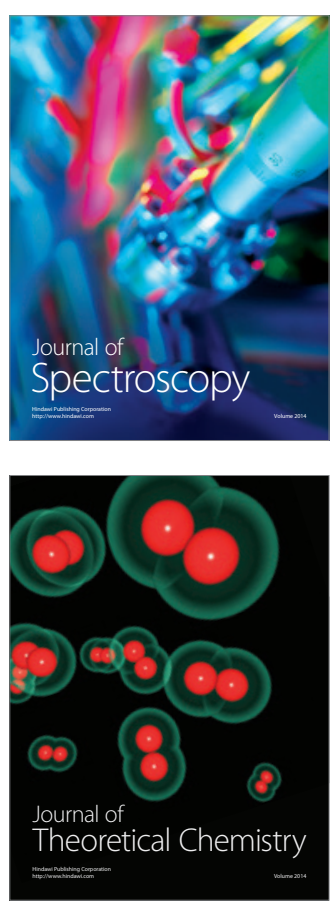
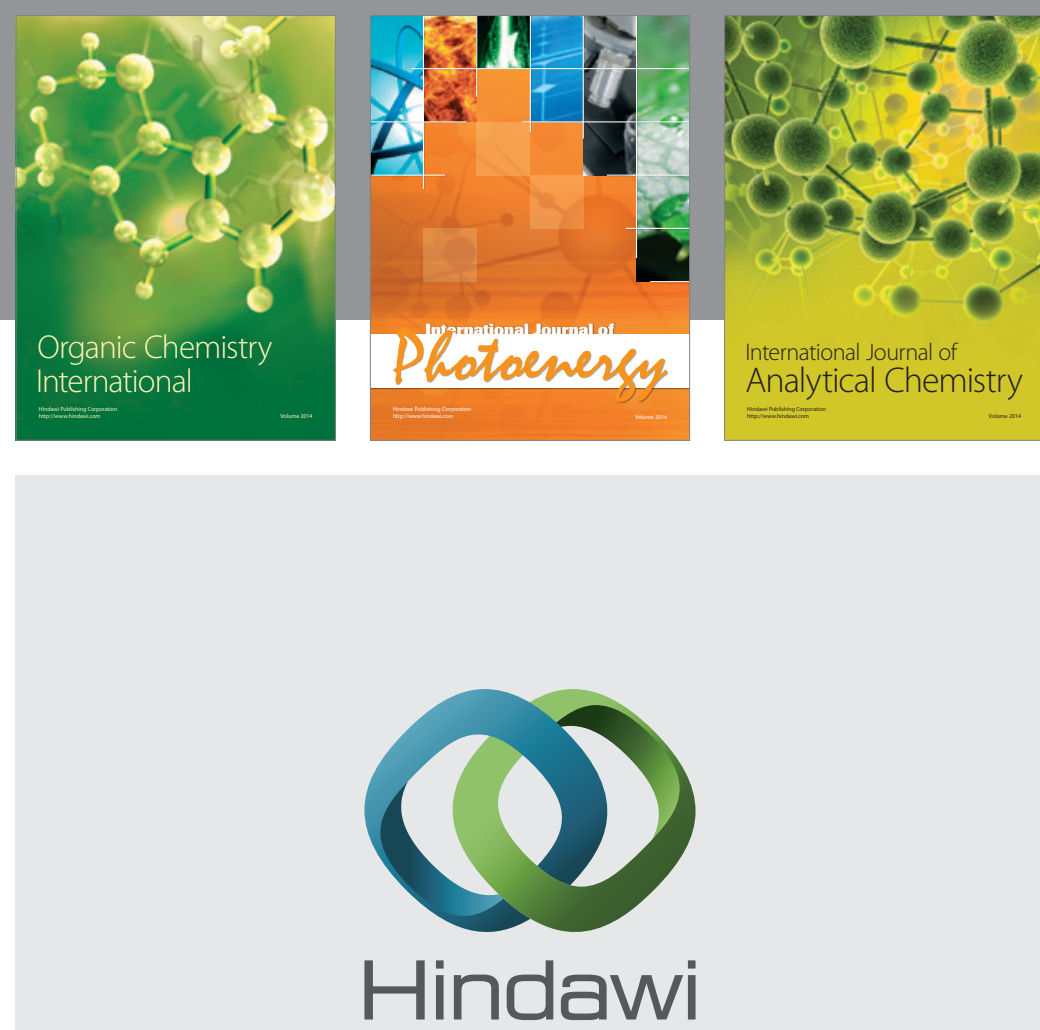

Submit your manuscripts at

http://www.hindawi.com
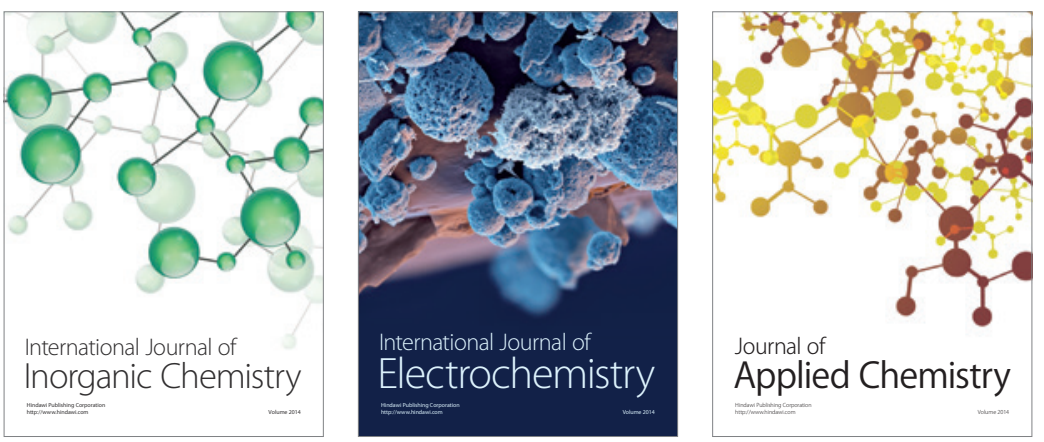

Journal of

Applied Chemistry
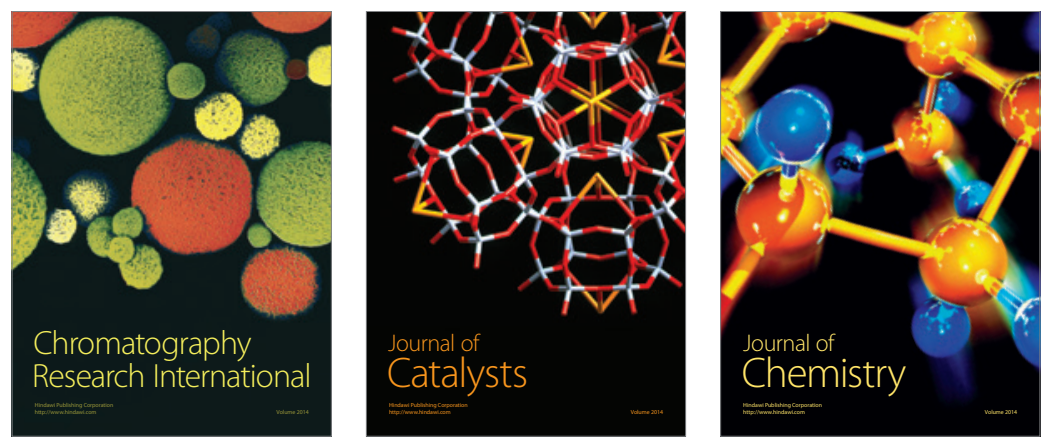
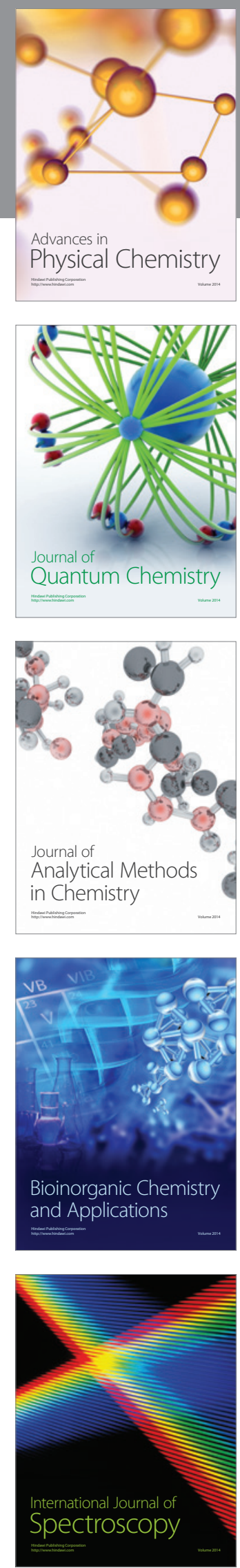